NBER WORKING PAPER SERIES

\title{
ASSESSING URBAN CRIME AND ITS CONTROL:
} AN OVERVIEW

\author{
Philip J. Cook
}

Working Paper 13781

http://www.nber.org/papers/w13781

\author{
NATIONAL BUREAU OF ECONOMIC RESEARCH \\ 1050 Massachusetts Avenue \\ Cambridge, MA 02138 \\ February 2008
}

Brian Forst, David Kennedy, Jens Ludwig, Michael Tonry, Joel Wallman, and Frank Zimring offered useful suggestions on earlier drafts. Erin Hye Won Kim provided excellent research assistance. The views expressed herein are those of the author(s) and do not necessarily reflect the views of the National Bureau of Economic Research.

NBER working papers are circulated for discussion and comment purposes. They have not been peerreviewed or been subject to the review by the NBER Board of Directors that accompanies official NBER publications.

(C) 2008 by Philip J. Cook. All rights reserved. Short sections of text, not to exceed two paragraphs, may be quoted without explicit permission provided that full credit, including $\odot$ notice, is given to the source. 
Assessing Urban Crime And Its Control: An Overview

Philip J. Cook

NBER Working Paper No. 13781

February 2008

JEL No. K42,L1

\begin{abstract}
Urban crime rates in the United States fell markedly during the 1990s and remain at historically low levels. The statistical evidence presented here indicates that that decline, like the crime surge that preceded it, has been largely uncorrelated with changes in socioeconomic conditions across cities. The ups and downs of crime have a considerable effect on residential location and property values. The police represent the largest public expenditure in city-level crime control efforts, and they are increasingly held accountable for reducing crime rates. Indeed, there is considerable evidence that an increase in police expenditures does pay off in the form of lower crime rates. This is an incomplete story, however. Assessments of police effectiveness typically neglect the considerable role of private and community-level protection and control efforts, not to mention the vital importance of (uncompensated) private inputs into police investigations. In areas with endemically high violence rates, the reluctance of witnesses to cooperate remains a serious problem.
\end{abstract}

Philip J. Cook

Terry Sanford Institute of Public Policy

Box 90245

Duke University

Durham, NC 27708

and NBER

pcook@duke.edu 
The great epidemic of youth violence that swept the nation's cities beginning in the mid-1980s finally crested in 1993 and has largely subsided since then. In many cities, rates of crime and violence are now at levels not seen since the Kennedy era. The remarkable turnaround has contributed to the current golden age in New York, Chicago, and elsewhere.

The epidemic has generated some important lessons. The first is that safe streets are a necessary platform for neighborhood growth and prosperity. Thus the notion that poverty is the mother of crime has been turned on its head. Second, a city's violence rates can be extraordinarily volatile. The homicide victimization rate for young black men increased by a factor of 10 in Washington, DC during the crack era of the late 1980s - not because the city was invaded by violent newcomers, but because of the drug-related conflict engendered within the existing population. The traditional "root causes" of crime - poverty, lack of parenting, limited licit opportunities - were operating in the background, but those factors only created a potential for trouble; the realization of that potential depended greatly on the immediate circumstances. Third, police resources and tactics have a direct effect on the crime rate.

This last lesson is perhaps most surprising and remains contentious. Criminologists and police chiefs had long agreed on one thing, that police bore no responsibility for the everyday violence in the city because they had no way to prevent it. But beliefs have changed. New policing strategies were introduced during the epidemicmost prominently problem-solving "community" policing and "broken windows" ordermaintenance policing - coupled with a new generation of chiefs who have declared they are accountable for lowering crime. Criminologists have provided some systematic evidence in support of their new strategies, although it is less than decisive. (The great crime decline of the 1990s made most any intervention look good.) In any event, there is solid evidence that more resources devoted to policing are generally productive in reducing crime.

The cities have also benefited from a secular decline in crimes like burglary and motor vehicle theft, for reasons that are even less well understood than the decline of violence. Private self-protection activities may get part of the credit. The private security 
industry continues to grow faster than public policing. Technical innovations have improved alarm and surveillance systems, which at the same time have become more pervasive. These innovations have the effect of improving the quality of information that private citizens provide law enforcement, and hence increasing the productivity of policing. But there is reason to believe that private cooperation remains a scarce resource, currently undersupplied. One key to more efficient crime control may be enhanced incentives for households and businesses to cooperate with the public aspects of the crime-control task.

The quest for efficiency is motivated in part by the burgeoning costs of the current criminal justice system, especially incarceration. The prison and jail population has quadrupled since 1980, imposing a considerable burden on taxpayers, not to mention the prisoners themselves. For African American males under age 40 who lack a high school diploma, imprisonment is almost as prevalent as licit employment. The quest for solutions to this evident failure of social policy can take two directions - improve licit opportunities, or be more parsimonious in the use of prison. But a third possibility is also promising, namely finding a more efficient public-private mix in crime control.

\section{A. Crime Measurement, Patterns, and Trends}

This section sets the stage for subsequent analysis by providing a brief introduction to crime measurement and then characterizing trends and patterns in crime.

\section{$\underline{\text { Measurement and data sources }}$}

The volume, trend, and patterns of crime can be measured by use of three sorts of data. The best-known source is the FBI's Uniform Crime Reports (UCR). Thousands of local law-enforcement agencies keep records of crimes reported or otherwise known to them, and of arrests, and compile this information according to definitions and guidelines provided by the UCR system. These compilations are forwarded to the FBI directly or through a state-level agency. Of the various crime categories included in the FBI's crime index, four indicate the volume of serious violence - rape, robbery (muggings, stickups, and other instances of theft through force or threat), aggravated assault (attacks that inflict or threaten serious injury), and criminal homicide. The UCR also tabulates data on 
reported burglaries (break-ins for the purpose of theft or other crime), larcenies, and motor-vehicle thefts.

Most agencies are quite faithful in tabulating and forwarding UCR data, but those data are necessarily an incomplete representation of serious crime. While the police are informed about most homicides, the same thing cannot be said about property crimes or even serious crimes of non-fatal violence, only a fraction of which are ever reported to the police. To unveil this "dark figure of crime" the US Department of Justice implemented an alternative system for measuring the volume of violence and other common crime in 1973. Since then the National Crime Victimization Survey (NCVS) has contacted large samples of households (currently about 45,000) to inquire whether any members age 12 and over have become crime victims during the preceding six months, and if so to provide details. The resulting estimates tend to be substantially larger than the UCR counts, and are also useful in providing the statistical basis for analyzing demographic patterns of violence - both of the victims, and of the perpetrators (based on respondents' reports of their impression of the age, race, sex, and number of assailants). The limitations of the NCVS data are intrinsic to the survey approach - the data are too sparse to provide reliable estimates of rates or trends of serious violence at the state or local level, or to provide sufficient data on rare events to support even national estimates. ${ }^{1}$ For that reason and for the more obvious reason (a survey requires a live respondent), the NCVS includes no information on homicides.

Fortunately that gap is filled by a third source, the Vital Statistics system. Coroners and medical examiners around the nation report the results of their investigations of deaths, which are compiled at the state and national level under the aegis of the National Center for Health Statistics. These mortality data are generally considered the most reliable source of information on homicide-victimization rates and patterns (Wiersema, Loftin \& McDowall 2000), although they are somewhat limited -the Vital Statistics provide no information on suspects or circumstances of the homicide.

It is possible to estimate trends and patterns in the commission rates of violent crime for different demographic groups, although that is necessarily more speculative. Arrest data provide some guidance, but most violent crimes do not result in an arrest and there is no reason to believe that arrestees are a representative sample of perpetrators. The 
NCVS data on assault and robbery perpetrators are better in that respect, but limited by small numbers and the ability of the respondents to recount the demographic characteristics of their assailant. Perhaps the most useful information is once again for homicide. Most police departments provide detailed data on homicides as part of the UCR. The Supplementary Homicide Reports (SHR) include the demographic characteristics of one or more suspects, and these characteristics in the remaining cases can be imputed using reasonable assumptions (Fox 2000; Cook \& Laub 2002). ${ }^{2}$

\section{$\underline{\text { Trends }}$}

Homicide rates, the most reliable indicator of violence, have followed a low-highlow pattern during the post-War period (Figure 1). During the 1950s homicide rates were about 5 per 100,000 residents. In 1964 rates began heading decisively upward, doubling by the end of the Vietnam era. There was some variation off this new high level for the next 20 years, with peaks in 1980 and 1991. A remarkable decline during the 1990s leveled out in 2000 at a rate approaching that of the early 1960 s. $^{3}$

Figure 1 here

For the period since 1973, the NCVS data provide victimization estimates that suggest that non-fatal violence has followed a similar trend. In particular, victimization rates for violent crime varied in a narrow range until 1994, and then dropped to less than half by 2002 (Figure 2). UCR robbery rates have followed homicide rates very closely throughout this period (Blumstein 2000; Blumstein \& Rosenfeld 2007).

Figure 2 here

NCVS data for property crime victimization indicate a sustained downward trajectory since 1980; the current rate is just one-third the peak level (Figure 3). Crime trends based on the UCR police statistics tell a similar story. For example, the NCVS burglary rate per 1,000 households declined 70\% since 1980 (from 100 to 30); during the same period, the UCR burglary rate per resident (which includes commercial burglaries) declined $57 \%$.

Figure 3 here

The extraordinary reduction in violent crime during the 1990s has been the object of extensive exegesis, by economists and others (Blumstein \& Wallman 2000; Cook \& 
Laub 2002; Zimring 2007; Blumstein \& Wallman 2006). No expert predicted this decline, and it remains something of a mystery. Steven Levitt (2004) provides a survey of potential causes. He first notes that the decline was quite universal, affecting all demographic groups and geographic areas. With respect to urbanicity, he observes that the greatest percentage improvements occurred within metropolitan statistical areas (MSAs) and especially among large cities with populations over 250,000. In fact, all the 25 largest cities experienced noteworthy declines in homicide rates from their peak year (mostly in the early 1990s) to 2001, declines that ranged as high as $73 \%$ for New York and San Diego. Based on his analysis, Levitt ends up awarding credit for the crime drop to increases in the number of police, the rising prison population, the receding crack epidemic, and the legalization of abortion through Roe v. Wade. His claim for the importance of abortion liberalization is controversial to say the least (Joyce 2004), but the rest of the list is widely endorsed by experts. His judgment about what is not important to the crime drop includes the sustained economic growth in the 1990s, and the muchballyhooed innovations in policing in New York and elsewhere.

Crime rates during the period 1984 to 2001 provide a graphic demonstration of their potential volatility, particularly for local areas and specific groups. ${ }^{4}$ Most notable was the nationwide epidemic in minority-youth violence that began in the mid 1980s and peaked in 1993, subsiding thereafter. For African American males, homicide commission rates increased by a factor of five for the 13-17 age group, and by a factor of nearly three for those aged 18-24 (Cook \& Laub 2002). For individual cities the swings were still larger: homicide involvement by young black men in Washington DC increased by a factor of ten during this period. The remarkable conclusion is that similar "fundamentals" of socioeconomic status are compatible with a homicide rate of both X and 10X, given relatively minor changes in circumstances. Franklin Zimring (2007) concludes his analysis of the crime drop "Whatever else is now known about crime in America, the most important lesson of the 1990s was that major changes in rates of crime can happen without major changes in the social fabric (p. 206)." That observation, reasonable as it sounds, is a rather profound revision of pre-epidemic conventional wisdom. 


\section{$\underline{\text { Patterns in Urban Crime }}$}

Despite the volatility of crime rates, the geography of crime tends to be rather stable and predictable. The crime map of any large city lights up in those neighborhoods that are also characterized by a high concentration of disadvantaged minorities, joblessness, single-parent households, drug abuse, substandard housing, inadequate public services, and high population turnover. It is only reasonable to suppose that that confluence of conditions holds the key to understanding the social and economic conditions that foster crime. Indeed, community characteristics associated with economic and social disadvantage are often seen as the "root causes" of youth crime and violence.

In the late 1960s, coinciding with the first post-War surge in crime rates, three presidential commissions argued in their final reports that redressing such problems was a necessary pre-condition for reversing the trend. The first of these, known as the President's Commission on Law Enforcement and the Administration of Justice, opined in 1967 that "The underlying problems are ones that the criminal justice system can do little about. ... They concern the Commission deeply, for unless society does take concerted action to change the general conditions and attitudes that are associated with crime, no improvement in law enforcement and administration of justice, ... will be of much avail (President's Commission on Law Enforcement and Administration of Justice 1967)." The 1968 report of the National Advisory Commission on Civil Disorders, the Kerner Commission, assigned much of the blame for the urban riots of the 1960s on the effects of racism, with the call for action couched in the now-famous observation that "Our nation is moving toward two societies, one black, one white - separate and unequal (United States Kerner Commission 1968).” A decade later, the National Commission on the Causes and Prevention of Violence observed that "Violence is like a fever in the body politic: it is but the symptom of some more basic pathology which must be cured before the fever will disappear (1969: xix)." Further, "the way in which we can make the greatest progress toward reducing violence in America is by taking the actions necessary to improve the conditions of family and community life for all who live in our cities, and especially for the poor who are concentrated in the ghetto slums (p. xxi)."

Socioeconomic conditions, then, served not only as an explanation for patterns of violence, but also as the pre-eminent candidates for intervention. Reducing disparity and 
disadvantage was presented as a feasible option, and the only approach that could do much good. While the 1960s are long gone, it seems fair to say that that perspective is still influential. These days we may be more sanguine about the ability of the police and prisons to reduce crime, and less sanguine about the feasibility of correcting root-cause conditions, but there remains a sense among many social scientists that the community, shaped in part by the larger societal context, is ultimately the right place to look for a satisfactory explanation of crime patterns.

Much of the systematic evidence available on the relationship between crime rates and environmental or "ecological" (the more common term) characteristics derives from multivariate regression analysis on cross sections of data on jurisdictions. (The jurisdictions may be anything from states down to Census tracts.) These studies typically include an eclectic list of explanatory factors. ${ }^{5}$ A recent example gives the flavor of these studies. Morgan Kelly (2000) analyzed crime rates in 1991 for the 200 largest U.S. counties, utilizing a variety of demographic and socioeconomic factors as explanatory variables. I have followed his lead, but with some modifications in his original regression specification. ${ }^{6}$ The results for robbery and homicide for 1990 and 2000 are reported in Table 1.

\section{Table 1 here}

The crime data are derived from the FBI's Uniform Crime Reports, and all other variables from the decennial Censuses. Since all variables are in log form, the coefficients are conveniently interpreted as "elasticities" - the percentage change in the dependent variable (crime rate) associated with a one percent increase in the explanatory variable. Thus, according to these results, a one percent increase in the county's population was associated in 2000 with a $0.11 \%$ increase in the robbery rate, and a $0.06 \%$ increase in the homicide rate, conditioned on the other explanatory variables.

These results provide general support for the "root causes" perspective for both the near-peak year (1990) and the post-decline year (2000) of the violence epidemic. Across urban counties, both robbery and homicide rates increase markedly with the prevalence of female-headed (one-parent) families; with population instability (as measured by the percentage of the population that changed addresses in the preceding five years); with income inequality, as measured by the Gini coefficient on household 
incomes; and with the prevalence of blacks in the population. The weak relationship with population and population density is surprising: contrary to expectation, the effects tend to be quite small and, with one exception, statistically insignificant. ${ }^{7}$ As it turns out, one consequence of differentially paced crime drop during the 1990s was to largely eliminate the long-established association between population size and violent-crime rates for cities above $250,000 .^{8}$

This type of study is the statistical equivalent of the crime map, demonstrating that serious violent crime rates tend to be highest in areas with the greatest disadvantage. Beyond that general finding, the results should be taken with a considerable dose of salt. Because different measures of "disadvantage" tend to be highly correlated with each other across jurisdictions, it is difficult to sort out the separate effects of, say inequality, prevalence of female-headed households, and prevalence of those with a college education. ${ }^{9}$ And there is a more fundamental problem: a statistical analysis of natural cross-section variation, while suggestive, really says little about causation. (For example, residential turnover may be just as much effect as cause of crime.) That fact was largely ignored by those panels of experts from the 1960s quoted above (Wilson 1974).

In any event, the criminogenic factors identified in the cross-section regressions for 1990 and 2000 did not improve during the 1990s. In fact, national income inequality increased markedly, as did the prevalence of single-parent households. Furthermore, in the 200-county sample, there was little tendency for the counties that showed relative improvement in these factors to exhibit a larger drop in robberies or murders than other counties. When the regression is run on decade-long changes in the variables, the only statistically significant coefficient is for "\% female headed households" in the case of murder; for robbery there are two marginally significant coefficients, for "\% black" and "\% college". An analysis of changes from 1980 to 1990 also found little in the way of statistical associations. ${ }^{10}$

The 1990s experience - the large across-the-board reduction in crime without much progress in the socioeconomic fundamentals - is hopeful, in a way. It creates the possibility that crime rates can change dramatically, quite independently of changes in the fundamental socioeconomic conditions. Thus crime is not only volatile but also 
potentially malleable, with policies more feasible and immediate than those required to "reshape society."

\section{B. Costs of crime}

In assessing crime policy, the costs of crime and the costs of crime prevention are equally important (Becker 1968). Reducing the total cost of crime and crime prevention becomes an important public goal, along with the goals of promoting greater justice and equity. Thus, whether it is worthwhile to increase resources devoted to public law enforcement depends in part on whether the projected reduction in crime has value greater than the additional expenditure. Getting the accounting right on the value of crime reduction is vital to setting priorities.

\section{$\underline{\text { Public Costs of Crime Prevention }}$}

The accounting of relevant crime-prevention costs begins with direct public expenditures. Table 2 provides a summary for 2003. In that year the total expenditure was $\$ 195$ billion ( $\$ 670$ per capita), about half of which was expended by counties and cities. Most local expenditures were for policing (\$58 billion) although county governments also have substantial responsibility for courts and jails. When compared with total expenditures by local governments, including education, transportation, and all else, police services account for about 5 percent.

\section{Table 2 here}

Figures 4 and 5 demonstrate the considerable growth in expenditures on criminal justice over the last quarter century. Adjusting for inflation and population growth, expenditures per capita have grown most rapidly at the federal level (for which the 2004 level was 3.2 times the 1982 level), then state (2.3 times) and then local (1.9 times), trending toward greater parity across the three levels of government. Across functions, the largest growth has been in corrections (where real expenditure per capita increased by a factor of 2.75), reflecting the burgeoning prison and jail populations.

Figures 4 and 5 here

There appears to be consensus among experts that the extraordinary run-up in the jail and prison population since 1980 (from a half million to over 2.2 million) gets some 
of the credit for the crime drop (Blumstein \& Wallman 2006; Levitt 2004). But that has come at considerable cost, both direct and indirect. The high rates of imprisonment have been a particular burden on the African American community. Steven Raphael and Melissa Sills report that roughly 11 percent of black men aged 18-40 were imprisoned as of 2000 (Raphael \& Sills forthcoming: 526\}. For high school dropouts in this demographic group, there are almost as many institutionalized as employed; in fact, for those aged 26-30, 34\% were institutionalized compared with $30 \%$ employed (p. 528). The high institutionalization rates for black males leaves a demographic gap in poorer minority communities, with important implications for family and community life. Those who are not actually in prison are likely to have a felony record, limiting their licit employment opportunities (Travis 2005; Western 2006). These ancillary effects of imprisonment should loom large in assessing alternative strategies to control crime.

Economists may debate whether the current level of imprisonment is too high or low, based on a comparison between estimated marginal costs and benefits, but there is no reason to believe that the current allocation of imprisonment is "efficient" from a crime control perspective. Much of the growth in imprisonment is accounted for by longer sentences (Blumstein \& Beck 2005), which have sharply diminishing returns with respect to both deterrence and incapacitation. ${ }^{11}$ There is a strong argument to be made for greater use of "intermediate" sanctions such as fines and intensive supervision in the community (Morris \& Tonry 1990). The fact that the 600,000 prisoners released each year usually receive little supervision or support suggests that a larger investment in prisoner reintegration might help reduce the high recidivism rate (about half returned to prison within three years). ${ }^{12}$ Furthermore, at the margin there are arguably more costeffective uses of the corrections budget in prevention, such as pre-school education or programs to encourage high-school graduation (Donohue \& Siegelman 1998; Lochner \& Moretti 2004). A worthy quest is to identify and implement an effective crime-control strategy that economizes on the use of prison.

\section{$\underline{\text { Private costs of security, precaution and victimization }}$}

The private provision of protection against crime is also costly. The Economic Census (conducted once every five years by the U.S. Census Bureau) provides an 
estimate of receipts of the private security industry in 2002 as $\$ 30$ billion, as compared to $\$ 80$ billion in public expenditures on police protection. ${ }^{13}$ (There may be some overlap in these numbers, since governments hire private security for some purposes.) But estimates of the number of employees suggest something closer to parity. There were just over 1 million police employees in 2002 (of which $75 \%$ were sworn officers), compared with 754,000 private security employees (Economic Census). In the decade from 1992 to 2002, private security employment grew 34\%, compared to a 27\% growth for police employees. Currently, then, there are about as many private security employees as sworn officers. ${ }^{14}$

Costs to businesses, organizations and households of crime prevention, avoidance, and victimization involve much more than the expenditures on criminal justice programs and private security. Crime and especially the threat of criminal victimization play a pervasive role in the life of the city. Shoplifting and fraud increase the cost of doing business for retailers. Vandalism, open-air drug dealing, prostitution, and loitering by gang members are neighborhood disamenities with tangible impacts on real estate values and patronage of local retailers. Perhaps most important is the threat of violence; people who have a choice will avoid dangerous neighborhoods, opting instead to live, work, shop, attend school, and recreate in safer places. In particular, the effect of crime on residential choice was documented by Julie Barry Cullen and Steven Levitt (Cullen \& Levitt 1999), who demonstrated that crime has a powerful effect on residential decisions. For people who do not have the means to relocate from crime-impacted neighborhoods, fear and seclusion may become a fact of life. This point was documented by the Moving to Opportunity experiment (which provided vouchers to low-income families to relocate in Boston and four other cities); by far the most important reason families signed up for the program was fear of crime and violence in the housing projects (Katz, Kling \& Liebman 2003).

Estimating the social cost of crime is challenging because so much of it is subjective. One approach to placing a dollar value on commodities like "safety from criminal victimization" -- commodities that are not traded in the marketplace -- is the contingent-valuation method. Economists have used this method most often in valuing environmental protection but Jens Ludwig and I adapted the method to valuing a 
reduction in the threat of gun assault in a community (Cook \& Jens Ludwig 2000). We asked a nationally representative survey sample a series of questions about how much they would be willing to pay in increased taxes for a program that would reduce interpersonal gun violence in their community by 30 percent. Based on the results, we estimated that the value of a 30 percent reduction to individuals would have been $\$ 24$ billion in 1995, suggesting that the total burden was about $\$ 80$ billion. This method has also been used to value general reductions in crime (Cohen 2005).

An alternative approach is to construct an estimate by adding up across the various elements of crime costs, both tangible (expenditures on security, medical costs from assault-related injuries) and intangible, being careful not to double count. A heroic effort to estimate the total for the United States by David Anderson (1999) arrived at an annual figure of $\$ 1.1$ trillion for the mid 1990s. Included in this figure were the value of risks to life and health from violent crime ( $\$ 574$ billion), time spent securing assets ( $\$ 90$ billion), and $\$ 397$ billion in "crime-induced production" (covering everything from drug trafficking to small arms purchases to expenditures by Mothers against Drunk Driving). Jens Ludwig updated this figure using data circa 2004, offering a new total of $\$ 2$ trillion (Ludwig 2006), over \$6,000 per capita.

Violent crime is a prominent component of these estimates, and reducing serious violence deserves correspondingly high priority. It is interesting to place this point in international context. Compared with other developed nations the United States has the reputation of having exceptionally crime-ridden cities. But in fact the U.S. compares favorably with other countries for common crimes of theft and burglary - it is robbery and assault in which we tend to be relatively high (Zimring \& Hawkins 1997). For homicide the victimization rate in the United States is a multiple of that in other developed nations, combining, as we do, a high assault rate with ready access to guns (Hemenway 2004). An emphasis on violence is also justified by the American public's values. In their contingent valuation study of a nationally representative sample of Americans, Mark Cohen and his associates found greater willingness to pay for a 10 percent reduction in homicide or rape than a 10 percent reduction of the far-morecommon crime of burglary (Cohen, et al. 2004). 
These attempts at valuation are static, while the effects of crime on a city neighborhood may well evolve over time. Indeed, effective crime control can do much to revitalize a blighted neighborhood. Without a doubt the great crime reduction of the 1990s gets some of the credit for the urban renaissance that occurred in one large city after another beginning in that period, with New York being the most notable case in point (Schwartz, Susin \& Voicu 2003). (President Bill Clinton would not have wanted his office in Harlem back in 1980.) None of the available estimates of the cost of crime successfully captures this dynamic, transformative possibility.

Note that we have now come complete circle. The geography of crime is closely linked to socioeconomic disadvantage, as suggested by the regression results in the previous section. It is quite reasonable to believe that income inequality, broken families and limited education create fertile ground for criminal activity. But the reverse may also be true. If crime rates are brought down to levels that are more acceptable to middle class households, then more of them may choose urban over suburban living - a process that will eventually change the socioeconomic makeup in ways associated with lower crime rates.

While crime has a large effect on the standard of living in cities, public responsibility for criminal justice policy is divided between local, state, and federal governments. In particular, courts, prisons, and parole are state and federal matters. The most important city and county responsibility is for policing.

\section{Police and crime control}

Police have the lead responsibility for responding to and preventing crime. Criminologists have traditionally questioned whether the police in fact have much influence on crime rates, and when crime is rising many a chief has blamed youth culture, the breakdown of family life, or unemployment. But a series of innovations in police management and methods, to some extent coincident with the crime drop of the 1990s, have led to a dramatic change in rhetoric. Now big-city police chiefs publicly embrace responsibility for controlling crime and seek guidance from evaluation research about how best to do so. Criminologists continue to debate best practice, but have become more open to the possibility that policing matters. Understanding just how it matters, and 
how it can be most effective, requires a strategic analysis of how the police interact with other institutions and the public at large.

\section{More police, less crime}

In 1994, David Bayley, one of the leading academic experts on policing, opined that "The police do not prevent crime. Experts know it, the police know it, but the public does not know it (1994)." As evidence of the public's ignorance in this respect, in 1994 Congress enacted the Violent Crime Control and Law Enforcement Act, which provided funding to local police departments to hire thousands of new police officers. Thanks in part to this federal funding, the number of police did increase substantially during the decade, peaking at 246/100,000 in 1999 (Zimring 2007: 178). Along with this expanding workforce came innovations in police deployment and management.

The first question is whether additional resources in policing tend to be deployed effectively, without regard to specific technique or strategy. It has proven difficult to statistically sort out the crime-control effect of police resources, since the causal connection goes both ways -cities may hire additional police in response to a crime increase. But several studies have found persuasive ways to isolate the causal effect of police resources on crime. William Evans and Emily Owens (2005) analyzed the effects of COPS funding on crime, finding that cities did indeed hire additional police after receiving federal funding and that the result was reduced crime rates. Another study analyzed variation in police presence in Washington, DC resulting from changes in the terror alert level, finding that the deployment of additional police reduced crime rates, especially on the National Mall (Klick \& Tabarrok 2005). In England and Wales, the Street Crime Initiative provided funding for anti-robbery policing in 10 of the 43 policeforce areas, with large, statistically discernible effects on robbery rates (Machin \& Marie 2005). Other studies have provided additional support for the conclusion that additional police suppress crime rates (Levitt 2002; McCrary 2002; Levitt \& Miles forthcoming). The effect sizes are large enough to make a strong case for expanded police funding (Donohue \& Ludwig 2007). While the "black box" nature of these estimates is somewhat troublesome - surely it matters how exactly the resources are used - it appears true that police departments know how to put additional resources to effective use. 
It should be noted that most all the evaluations of increased policing have been incomplete, in the sense that they have failed to measure the ancillary costs and benefits. The expansion of policing may well result in an increase in downstream costs associated with additional arrests, convictions, and incarcerations - but not necessarily, and there is no good evidence on this matter (Levitt \& Miles forthcoming). ${ }^{15}$ Furthermore, the increase in public policing may well have an effect on private-security and self-protection efforts, an area that has been almost entirely neglected in these evaluations.

\section{Innovations in Policing}

Surely the crime-control effects of police manpower and expenditures depend on organization and tactics. If so, the answer to the question of whether it is worthwhile to expand policing may well be "it depends." The evidence reviewed in the previous section suggests that there are cost-effective uses for additional police resources and police chiefs typically know enough to make use of them. But there remains a good deal of debate about the most efficient use of resources.

A review of the evidence on police practice by an expert panel of the National Academy of Sciences (Skogan \& Frydl 2004: 5) defined these innovations relative to the traditional "standard model" of policing, which consists of preventive patrol, rapid response to 911 calls, follow up investigations by detectives, and unfocused enforcement efforts. Police departments innovated away from this standard model by adopting more focused tactics designed to address specific problems, such as gun use by drug-dealing gangs, or "hot spot" locations where crimes are frequently reported. William Bratton, appointed New York Police Commissioner in 1994, took this approach another step by combining focused policing with a new management accountability system, familiarly known as COMPSTAT. In this system, precinct commanders are given considerable authority, responsibility and discretion over resources, coupled with responsibility for reducing crime in their command areas. Weekly meetings are held at headquarters to discuss solutions to emerging crime problems in each of the precincts, as documented by the COMPSTAT Report (a computerized version of the old pin map), and a wide range of qualitative information at the borough and precinct level. The focus on reducing crime, 
rather than on process-oriented performance measures (response times to 911 calls, arrest rates, complaints) is a profound change.

In many departments, proactive, focused policing has been embedded in one of two broad strategies. The first is community policing, in which the police seek to develop a productive working relationship with the community that encourages cooperation in crime prevention, including the identification and solution of neighborhood problems. The traditional emblematic features of community policing were Neighborhood Watch organizations and foot patrol by police in high-crime neighborhoods; more recently the focus is on information-sharing and problem-specific operational partnerships with community organizations. The 1994 Act that provided federal funding for more police also created the Office of Community Oriented Policing Services (COPS) in the US Department of Justice, thus giving a federal imprimatur to this strategy.

An alternative strategy known as "broken windows policing" (also known as "order maintenance," "zero tolerance," and "quality of life" policing) has also garnered converts among police departments. The approach has its origin in an essay in the Atlantic Monthly by James Q. Wilson and George Kelling (1982). It was adopted by Bratton and has been credited by him and others with the New York "miracle" (Kelling \& Sousa 2001; Bratton \& Knobler 1998). The theory behind this approach is that minor social disorder, such as graffiti, litter, public drinking, panhandling, and abandoned buildings, engenders crime by serving as a signal that normal social control has broken down (Harcourt \& Ludwig 2006). Its implementation in New York and elsewhere has taken the form of aggressive policing with numerous arrests for public-disorder misdemeanors, sometimes at the cost of good relations with the community.

Objective evaluations of the New York innovations - COMPSTAT and aggressive "order maintenance" policing -- have reached differing conclusions (Harcourt \& Ludwig 2006; Rosenfeld, Fornango \& Baumer 2005; Rosenfeld, Fornango \& Rengifo 2007; Zimring 2007). A broader consensus has emerged supporting the efficacy of concentrating police resources in "hotspots" and directing patrol against illicit gun carrying and other criminogenic activities and circumstances (Sherman 2002; Cohen \& Ludwig 2003; Braga 2005; Eck \& Maguire 2000; Skogan \& Frydl 2004). And it is hard 
to argue with the "problem solving" approach embraced by most big-city police departments, that seeks to prevent crime by finding ways to intervene where there is an ongoing source of trouble - a rowdy bar, perhaps, or a feud between rival gangs, or a dealer selling guns to youths and criminals. Effective interventions may require bringing in other government agencies (the alcohol licensing authority, for example) or enlisting the help of churches and other groups that have credibility and influence on the street.

No matter how creative the problem-solving effort, though, a zero crime rate is not a realistic goal. "Zero tolerance" is a myth. Faced with inevitable scarcity of their capacity for effective action, and the resulting tradeoffs, the police necessarily set priorities with respect to the various services they provide the community, and among different crime problems. A case in point is the now-famous Operation Ceasefire, organized by the Boston Police Department working with other law enforcement agencies and a team of analysts from Harvard. Confronted with a surge in lethal violence by drug-dealing gangs, they announced a program that focused enforcement efforts on the misuse of guns. In the absence of gunplay, gangs could continue dealing drugs subject to no more than the usual enforcement effort, but gang members were informed directly that gunplay by any one member of a gang would result in a heavy police crackdown on all the gang's activities (Kennedy, Piehl \& Braga 1996). The priority on gun misuse is also a long-standing feature of policing in Chicago (Cook, et al. 2007). The emphasis on guns over drugs has been widely endorsed by the public. The appropriate priorities are of course a value judgment, which ideally should in some sense represent the interests of the community, diverse though they may be (Moore 2002).

Police chiefs can no longer get away with denying responsibility for crime in their cities. Accountability for crime reduction has stimulated interest in evaluation information about effective approaches to crime control. But reliable information is scarce indeed. The "technology" of crime control (if that is the right word) is as complex as any other social process.

D. Private inputs in crime-control

Private security, and private crime-control efforts more generally, constitute an unwritten chapter in the recent literature on "what works" in crime-control policy. 
Observed crime rates and patterns reflect private choices regarding cooperation and selfprotection (Clotfelter 1977; Cook 1986). A systematic approach to public crime control requires understanding of the potential interactions between private efforts and public.

A place to begin the discussion of this complex topic is with the private security industry. The current scope of the private security industry is difficult to assess, but as previously recounted, the number of employees is at least as large as the number of sworn officers. It encompasses proprietary (in-house) security, guard and patrol services, alarm services, private investigations, armored car services, and security consultants, as well as security equipment (Cunningham, Strauchs \& Van Meter 1990). Private security supplements and in some cases substitutes for public action: for example, businesses in many cases investigate and resolve employee theft and fraud without ever going public. More generally, as noted by Brian Forst, "the central functions of policing - preserving domestic peace and order, preventing and responding to crimes - have always been conducted first, foremost, and predominantly by private means... Most crimes still are not reported to the police (1999: 19)."

Private security guards (and police officers who moonlight as private security guards) serve a narrow purpose, namely to protect the property and people they are hired to protect. The term of art is "situational crime prevention (Clarke 1983)." The guard's job is accomplished if the robbers avoid his bank, or his corporate executive is not kidnapped, or rowdy teenagers are successfully kicked out of his shopping mall, or the would-be burglar does not enter his gated community. "Rather than deterring crime through the threat of detection, arrest, and punishment, private policing tries to regulate behavior and circumstances to diminish the possibility that crime will occur (Bayley \& Shearing 2001: 18)."

An obvious possibility is that the crime will simply be displaced to other, unguarded victims and places. If private security does not prevent but only redistributes crime, then its public value (as opposed to private) is nil, and it creates serious equity concerns. ${ }^{16}$

While displacement is a legitimate concern, it is not the whole story. Lucrative opportunities, if unguarded, are likely to generate crime that would not otherwise occur. In Isaac Ehrlich's (1974) classic formulation, the supply of offenses is a function of the 
relative wage rate to licit and illicit activities. An increase in the net return (payoff per unit of effort) to crime will stimulate participation in criminal activity. He postulates that the payoffs to property crimes "depend, primarily, on the level of transferable assets in the community, that is, on opportunities provided by potential victims of crime (p. 87)." But if the most lucrative "transferable assets" are well protected, then the payoff to crime, and crime rates, is reduced. Of course, it is the most lucrative targets that do tend to be the best guarded. Banks invest more in security against robbery than, say, travel agencies. Jewelry stores display costume jewelry on open racks but keep the real thing in glass cases wired with alarms. People with meager assets do not need bodyguards to protect against being kidnapped for ransom. Credit card companies have instituted elaborate systems for preventing fraudulent use.

In fact there is a reasonable concern that some private precautionary activities are undersupplied due to the moral hazard created by insurance and even by the police. For example, a vehicle left unlocked in a public location invites theft, but the owner may be willing to accept that risk knowing that the police will attempt to recover his vehicle at public expense if it is reported stolen -- and that in any event he is insured against theft for most of the vehicle's value. The same considerations may dictate against purchasing alarms and other anti-theft devices. In response, insurance companies may provide a discount on theft insurance to owners who install such devices, and 12 states mandate these discounts. The mandate reflects a perceived public interest in increasing private precaution in this case.

Not all private actions to prevent or mitigate crime are limited to one's own household or business. The notion of "community" suggests neighbors looking out for each other, including with respect to crime. A tight-knit community may limit opportunities for crime by controlling the streets and sidewalks, keeping strangers under surveillance, and placing a check on local teenagers. This notion was given a scientific basis utilizing data from the Project on Human Development in Chicago Neighborhoods. A survey-based measure labeled "community efficacy" (a combination of items measuring informal social control and social cohesion) was found to be highly negatively correlated with crime and violence rates, even after accounting for some other features of the neighborhood (Sampson, Raudenbush \& Earls 1997). There is great interest and 
apparent success in crafting deliberate interventions to strengthen social control through public-community partnerships mobilized to confront chronic youthful offenders (Kennedy 2007).

In sum, private security and precautionary activities reduce crime rates by reducing the quality of criminal opportunities, and in that sense supplement public policing. Both are necessary. Private measures cannot cope efficiently with anarchy they need to be backed up by police with their extraordinary power of arrest. Public and private efforts are further interrelated by the fact that effective law enforcement requires close cooperation with the community.

\section{Increasing private input to public law enforcement}

One important aspect of the police department's mission is to reduce crime. Despite the newfound interest in prevention, much police work remains reactive. Crimes that are not reported to the police by private citizens will never be investigated. If the victim reports but does not cooperate with the investigation, it will likely be dropped, and if witnesses are not cooperative it is unlikely to go very far. In this set of transactions, we might say that public safety is being produced with inputs of both law-enforcement resources and of information from private citizens (Clotfelter 1993). The resulting enhancement of public safety benefits the entire community.

While the police depend on the public to report crimes, assist in investigations, and serve as witnesses in court, these key inputs are uncompensated and are supplied in some cases at considerable personal cost, inconvenience, and even risk of retaliation. Even victims are unlikely to benefit in any tangible way from cooperation with police, and most victims do not bother to even report the crime. ${ }^{17}$ In essence the citizens who become involved in a crime are invited to make a charitable contribution of their time and possibly their safety, in exchange for knowing they have done a good deed for their community. Better cooperation from victims and other citizens would increase police effectiveness, but it would help to better align private incentives.

A good place to start in eliciting greater cooperation might be reducing the private costs of cooperating. State victim-compensation programs provide some incentive for victims who are injured in violent attacks, since payment is contingent on reporting the 
crime. (Private insurance policies often stipulate that police be informed of a property theft as well.) Witness coordinators in criminal court can assist victims and other state witnesses in scheduling and understanding court proceedings. Police can offer some protection for witnesses that fear retaliation, although local resources for such efforts tend to be all too meager (Kocieniewski 2007).

In some cases the information needed for a successful investigation of crimes requires some prior action. For example, in the case of motor vehicle theft, it is helpful to investigators to be able to prove the rightful ownership of a vehicle or its constituent parts. Registered vehicle identification numbers (VINs) do not discourage theft directly (since they are hidden) but do facilitate building a legal case against a chop shop owner and others involved in the network. In fact, the federal government requires VINs on various parts of new vehicles. The result is to create a general deterrent to theft, a result that could not be achieved without government regulation. (The self-interested vehicle owner receives little benefit from his own vehicle's VIN, and he would not be willing to pay the cost voluntarily.) A similar logic applies to electronic tracking devices such as Lojack. Ian Ayres and Steven Levitt (1998) demonstrated that Lojack has large positive externalities in deterring auto theft. Because much of the benefit is external, the likely result is that too few people will voluntarily equip their vehicles with Lojack. ${ }^{18}$

Information is needed to prevent serious crimes as well as solve them. In the spate of school rampage shootings that culminated in Columbine, one of the commonalities was that perpetrators had shared their plans with classmates, and that the classmates had not seen fit to report this information to authorities (Newman 2004). While the causes of these distressing events were multiple and diffuse, a targeted prevention strategy would necessarily give high priority to persuading adolescents to pass on such information. Of course there is a strong parallel here to terrorist conspiracies of all kinds post $9 / 11$. More mundane is the routine urban problem of gun carrying by dangerous people, where before there is an actual victim there is a possibility of preempting violence by alerting the police. With that thought a number of police departments, including New York's, have established programs that offer a generous reward for a tip leading to arrest of a gun violator, with guarantees that the tipster remains anonymous. 
More broadly it is important for the police to be viewed as serving the interests of the community. Developing a healthy working partnership between police and community is the essence of the community-policing ideal. ${ }^{19}$

\section{E. Concluding Thoughts}

Crime control deserves priority in urban policymaking. High crime rates are a drag on community development and a great burden on households that cannot afford to move out. Successful control of theft, vandalism, public disorder (often associated with drug selling), and especially violence sets the stage for increasing property values, investment, job growth, and a higher standard of living. The fact that most large cities are far safer today than in 1990 has contributed to their growth and prosperity. But crime rates can be remarkably volatile - more so than other social indicators - and require continuing attention.

What recent history teaches us is that large fluctuations in crime rates can occur without much change in underlying socioeconomic conditions. While crime tends to be concentrated in low-resource neighborhoods year in and year out, crime rates are not uniquely determined by the socioeconomic conditions. That is fortunate. If eradicating entrenched problems of race, class, and culture were a precondition to successful crime reduction, then the crime agenda would have to be put on hold for a generation. But that is clearly not the case. Crime is a problem worth the mayor's attention because there is hope of making progress.

Of course many of the policies that influence crime rates in a city are not under the control of city government. It is the state legislatures that write the criminal code and establish sentencing rules for judges. Corrections is primarily a state or federal function as well. A host of other state and federal policies and programs outside the criminal justice system arguably affect crime rates: to name a few, those influencing immigration, gun availability, the price of alcoholic beverages, mental health treatment, abortion policy, child care, school attendance laws, insurance regulation, and regulation of violent content in the media. But the mayor's portfolio is by no means empty.

Front and center is the police department. One lesson from the 1990s crime drop is that police provide an effective deterrent to crime, and that increasing resources in 
policing has generally reduced crime. Part of the credit may go to innovations in policing tactics and management, although that is not entirely clear. With greater respect for the powers of the police has come a greater demand for evidence on what works in terms of organization and tactics. Police chiefs are being held responsible for controlling crime, just as school administrators are now held responsible for improving test scores.

The police operate in the context of the communities they serve. A strategic analysis of crime control should consider ways to encourage the public to do their part to restrict criminal opportunities and increase the strength of the criminal justice deterrent. It cannot be irrelevant that there are as many private security guards as sworn officers nationwide, performing somewhat overlapping functions. Businesses and households make myriad decisions that influence their exposure to criminal victimization and the profitability of crime. The criminal justice system of course has a key role, but it depends to a large extent on the voluntary cooperation of the public. Victims and other members of the public are called on to provide costly and largely uncompensated inputs in producing the public good of safe streets. There is much yet to be learned about how to enhance the private provision of this public good. 
References

Anderson, David A. (1999). "The Aggregate Burden of Crime," Journal of Law and Economics 42, 2, October, 611-642.

Ayres, Ian, and Steven D. Levitt. (1998). "Measuring Positive Externalities from Unobservable Victim Precautions: An Empirical Analysis of Lojack," Quarterly Journal of Economics 113, 1, 43-77.

Bayley, David H. (1994). Police for the Future. New York: Oxford University Press. Bayley, David, and Clifford Shearing. (2001). "The New Structure of Policing: Description, Conceptualization, and Research Agenda.". Washington, DC: National Institute of Justice.

Becker, Gary S. (1968). "Crime and Punishment: An Economic Approach," Journal of Political Economy 76, 2, 169-217.

Blumstein, Alfred. (2000). "Disaggregating the Violence Trends." In Alfred Blumstein, and Joel Wallman (eds.), The Crime Drop in America. New York: Cambridge University Press, 13-44.

Blumstein, Alfred, and AJ Beck. (2005). "Reentry as a Transient State Between Liberty and Recommitment." In J Travis, and C Visher (eds.), Prisoner Reentry and Crime in America. New York: Cambridge University Press, 07/04/29.

Blumstein, Alfred, and Richard Rosenfeld. (2007). "Factors Contributing to U.S. Crime Trends." Prepared for the National Research Council Workshop: Undersganding Crime Trends. . Washington, DC, 24-25/April.

Blumstein, Alfred, and Joel Wallman. (2000). The Crime Drop in America. New York: Cambridge University Press.

Blumstein, Alfred, and Joel Wallman. (2006). "The Crime Drop and Beyond," Annual Review of Law and Social Science 2, 125-146.

Braga, Anthony A. (2005). "Hot Spots Policing and Crime Prevention: A Systematic Review of Randomized Controlled Trials," Journal of Experimental Criminology 1, 317-342.

Bratton, William, and Peter Knobler. (1998). Turnaround: How America's Top Cop Reversed the Crime Epidemic. New York: Random House. 
Clarke, Ronald V. (1983). "Situational crime prevention: Its theoretical basis and practical scope." In Michael Tonry, and Norval Morris (eds.), Crime and Justice: An Annual Review of Research, Vol. 4. Chicago: University of Chicago Press.

Clotfelter, Charles T. (1977). "Public services, private substitutes, and the demand for protection against crime," American Economic Review, December, 867-877.

Clotfelter, Charles T. (1993). "The Private Life of Public Economics," Southern Economic Journal 59, 4, 579-596.

Cohen, Jacqueline, and Jens Ludwig. (2003). "Policing Gun Crimes." In Jens Ludwig, and Philip J. Cook (eds.), Evaluating Gun Policy. Washington, DC: Brookings Institution Press, 217-239.

Cohen, Mark A. (2005). The Costs of Crime and Justice. New York: Routledge.

Cohen, Mark A., Roland T. Rust, Sara Steen, and Simon T. Tidd. (2004). "Willingnessto-Pay For Crime Control Programs," Criminology 42, 1, February, 89-109.

Cook, Philip J. (1980). "Reducing Injury and Death Rates in Robbery," Policy Analysis, Winter, 21-45.

Cook, Philip J. (1985). "The Case of the Missing Victims: Gunshot Woundings in the National Crime Survey," Journal of Quantitative Criminology 1, 1, 91-102.

Cook, Philip J. (1986). "The Relationship Between Victim Resistance and Injury in Noncommerical Robbery," Journal of Legal Studies 15, 1, 405-416.

Cook, Philip J., and J.H. Laub. (2002). "After the Epidemic: Recent Trends in Youth Violence in the United States." In Tonry M. (ed.), Crime and Justice: A Review of Research. Chicago: University of Chicago Press, 117-153.

Cook, Philip J., and Jens Ludwig. (2000). Gun Violence: The Real Costs. New York: Oxford University Press.

Cook, Philip J., and Jens Ludwig. (2003). "The Effects of Gun Prevalence on Burglary: Deterrence vs. Inducement." In Jens Ludwig, and Philip J. Cook (eds.), Evaluating Gun Policy. Washington, DC: Brookings Institution Press, 74-118.

Cook, Philip J., and Jens Ludwig. (2006). "The social costs of gun ownership," Journal of Public Economics 90, 1-2, Jan., 379-391. 
Cook, Philip J., Jens Ludwig, Sudhir A. Venkatesh, and Anthony A. Braga. (2007). "Underground gun markets," The Economic Journal 117(524), November: 588618.

Cullen, Julie Berry, and Steven D. Levitt. (1999). "Crime, Urban Flight and the Consequences for Cities," Review of Economics and Statistics 81, 2, 159-169.

Cunningham, William C., John J. Strauchs, and Clifford W. Van Meter. (1990). Private Security Trends 1970 to 2000: The Hallcrest Report II. Boston: ButterworthHeinemann.

Donohue, John J., and Jens Ludwig. (2007). "More COPS," Policy Brief\#158. The Brookings Institution.

Donohue, John J., and Peter Siegelman. (1998). "Allocating Resources Among Prisons and Social Programs in the Battle Against Crime," Journal of Legal Studies 27, 143.

Eck, John, and Edward Maguire. (2000). "Have Changes in Policing Reduced Violent Crime?" In Alfred Blumstein, and Joel Wallman (eds.), The Crime Drop in America. New York: Cambridge University Press, 207-265.

Ehrlich, Isaac. (1974). "Participation in illegitimate activities: An economic analysis." In Gary S. Becker, and William M. Landes (eds.), Essays in the Economics of Crime and Punishment. New York: National Bureau of Economic Research.

Evans, William N., and Emily Owens. (2005). "Flypaper COPS." Working Paper. . University of Maryland Department of Economics.

Forst, Brian. (1999). "Policing with Legitimacy, Efficiency, and Equity." In Brian Forst, and Peter Manning (eds.), The Privatization of Policing: Two Views. Washington, DC: Georgetown University Press, 1-48.

Fox, James Alan. (2000). "Demographics and U.S. Homicide." In Alfred Blumstein, and Joel Wallman (eds.), The Crime Drop in America. New York: Cambridge University Press.

Freeman, Scott, Jeffrey Grogger, and Jon Sonstelie. (1996). "The spatial concentration of crime," Journal of Urban Economics 40 (September), 216-231.

Glaeser, Edward L., and Bruce Sacerdote. (1999). "Why Is There More Crime in Cities?" The Journal of Political Economy 107, 6, December, 225-258. 
Glaeser, Edward L., Bruce Sacerdote, and Jose A. Scheinkman. (1996). "Crime and Social Interactions," Quarterly Journal of Economics 111, 2, 507-548.

Harcourt, Bernard E., and Jens Ludwig. (2006). "Broken Windows: New Evidence from New York City and a Five-City Social Experiment," University of Chicago Law Review 73, 278-287.

Hemenway, David. (2004). Private Guns, Public Health. Ann Arbor, MI: University of Michigan Press.

Joyce, Theodore. (2004). "Did legalized abortion lower crime?" Journal of Human Resources 39, 1, 1-28.

Katz, Lawrence F., Jeffrey R. Kling, and Jeffrey B. Liebman. (2003). "The Early Impacts of Moving to Opportunity in Boston." In John Goering, and Judith Feins (eds.), Choosing a Better Life: Evaluating the Moving to Opportunity Social Experiment. Washington, DC: The Urban Institute Press.

Kelling, George, and William H. Sousa, Jr. (2001). "Do Police Matter? An Analysis of the Impact of New York City's Policy Reforms.". Manhattan Institute Civic Report, December.

Kelly, Morgan. (2000). "Inequality and Crime," Review of Economics and Statistics 82, 4, November, 530-539.

Kennedy, David M. (2007). "Making communities safer: Youth violence and gang interventions that work," testimony before the House Judiciary Subcommittee on Crime, Terrorism, and Homeland Security, Feb. 15.

Kennedy, David M., Anne M. Piehl, and Anthony A. Braga. (1996). "Youth Violence in Boston: Gun Markets, Serious Youth Offenders, and a Use-Reduction Strategy," Law and Contemporary Problems 59, 1, 147-198.

Klick, Jonathan, and Alexander Tabarrok. (2005). "Using Terror Alert Levels to Estimate the Effect of Policy on Crime," The Journal of Law and Economics 48, 267-279. Kocieniewski, David (2007). "Few choices in shielding of Witnesses," New York Times New York region: Oct. 28.

Land, Kenneth C., McCall Patricia L., and Lawrence E. Cohen. (1990). "Structural Covariates of Homicide Rates: Are There Any Invariances across Time and Social Space?" American Journal of Sociology 95, 4, 922-963. 
Levitt, Steven D. (2004). "Understanding Why Crime Fell in the 1990s: Four Factors That Explain the Decline and Six That Do Not," Journal of Economic Perspectives 18, 1, 163-190.

Levitt, Steven D., and Thomas J. Miles. (forthcoming). "The Empirical Study of Criminal Punishment." In A. Mitchell Polinsky, and Steven Shavell (eds.), The Handbook of Law and Economics.

Levitt, Steven. (2002). "Using Electoral Cycles in Police Hiring to Estimate the Effects of Police on Crime: A Reply," American Economic Review 92, 4, 1244-1250.

Lochner, Lance, and Enrico Moretti. (2004). "The effect of education on crime: evidence from prisoner inmates, arrests, and self-report," American Economic Review 94, 1, March, 155-189.

Ludwig, Jens. (2006). "The Costs of Crime." Testimony. . United States Committee on the Judiciary, 19 September.

Ludwig, Jens and Philip J. Cook (2001). "The Benefits of Reducing Gun Violence: Evidence from Contingent-Valuation Survey Data" Journal of Risk and Uncertainty 22(3), 2001: 207-226.

Machin, Stephen J., and Oliver Marie. (2005). "Crime and Police Resources: The Street Crime Initiative." IZA Discussion Paper No. 1853, November.

McCrary, Justin. (2002). "Using electoral cycles in police hiring to estimate the effect of police on crime: Comment," American Economic Review 92, 4, September, 12361243.

Moore, Mark H. (2002). Recognizing Value in Policing: The Challenge of Measuring Police Performance. Police Executive Research Forum.

Morris, Norval, and Michael Tonry. (1990). Between Prison and Probation: Intermediate Punishments in a Rational Sentencing System. New York: Oxford University Press.

National Research Council (2008). Parole, Desistance from Crime, and Community Integration. Committee on Community Supervision and Desistance from Crime. Washington, DC: The National Academies Press.

Newman, Katherine S. (2004). Rampage: The Social Roots of School Shootings. New York: Basic Books. 
Philipson, Tomas J., and Richard A. Posner. (1996). "The Economic Epidemmiology of Crime," Journal of Law and Economics 39 (October), 405-433.

President's Commission on Law Enforcement and Administration of Justice. (1967). To Challenge of Crime in a Free Society. Washington, DC: U.S. Government Printing Office.

Raphael, Steven and Melissa Sills (forthcoming). "Urban crime, race, and the criminal justice system in the United States." In Daniel P. McMillen and Richard Arnott, eds., Companion to Urban Economics. New York, Blackwell Publishing, 515535.

Rosenfeld, Richard, Robert Fornango, and Eric Baumer. (2005). "Did Ceasefire, Compstat, and Exile Reduce Homicide?" Criminology and Public Policy 4, 419450.

Rosenfeld, Richard, Robert Fornango, and Andres Rengifo. (2007). "The Impact of Order-Maintenance Policing on New York City Robbery and Homicide Rates: 1988-2001," Criminology 45, 2, 355-384.

Sampson, Robert J., Stephen Raudenbush, and Felton Earls. (1997). "Neighborhoods and Violent Crime: A Multilevel Study of Collective Efficacy," Science 277, 918-924. Schwartz, Amy Ellen, Scott Susin, and Ioan Voicu. (2003). "Has Falling Crime Driven New York City's Real Estate Boom?" Journal of Housing Research 14, 1, 101 135.

Sherman, Lawrence W. (2002). "Fair and Effective Policing." In James Q. Wilson, and Joan Petersilia (eds.), Crime: Public Policies for Crime Control. Institute for Contemporary Studies: Oakland, CA, 383-412.

Skogan, Wesley, and Kathleen Frydl. (2004). Fairness and Effectiveness in Policing: The Evidence. Washington, DC: The National Acedemic Press.

Travis, Jeremy. (2005). But They All Come Back: Facing the Challenges of Prisoner Reentry. Washington, DC: Urban Institute Press.

U.S. National Commission on the Causes and Prevention of Violence. (1969). To Establish Justice, to Insure Domestic Tranquility: Final Report. Washington, DC: U.S. Government Printing Office. 
United States Kerner Commission. (1968). Report of the National Advisory Commission on Civil Disorders. Washington, DC: U.S. Government Printing Office.

Western, Bruce. (2006). Punishment and Inequality in America. New York: Russell Sage Foundation.

Wiersema, Brian, Colin Loftin, and David McDowall. (2000). "A Comparison of Supplementary Homicide Reports and National Vital Statistics System Homicide Estimates for U.S. Counties," Homicide Studies 4, 317-340.

Wilson, James Q. (1974). "Crime and the Criminologists," Commentary 58, 1, July, 4753.

Wilson, James Q., and George L. Kelling. (1982). "Broken windows: The police and neighborhood safety," The Atlantic Monthly, March.

Wintemute, Garen. (2000). "Guns and Gun Violence." In Alfred Blumstein, and Joel Wallman (eds.), The Crime Drop in America. New York: Cambridge University Press, 45-96.

Zimring, Franklin E. (2007). The Great American Crime Decline. New York: Oxford University Press.

Zimring, Franklin E., and Gordon Hawkins. (1997). Crime is Not the Problem: Lethal Violence in America. New York: Oxford University Press. 
Table 1

Regression Analysis of Robbery and Homicide Rates/100,000 residents 200 Largest U.S. Counties (48 states), 1990 and 2000

(All variables are in natural log form)

\begin{tabular}{|c|c|c|c|c|}
\hline Explanatory Variable & Robbery 1990 & Robbery 2000 & $\begin{array}{c}\text { Homicide } \\
1990\end{array}$ & $\begin{array}{l}\text { Homicide } \\
2000\end{array}$ \\
\hline Intercept & -13.402 & -10.57 & -8.937 & -8.174 \\
\hline Population & 0.104 & 0.114 & 0.061 & 0.065 \\
\hline Population/square mile & 0.138 & 0.079 & 0.080 & 0.009 \\
\hline Per capita income & 0.466 & -0.260 & -0.401 & -0.761 \\
\hline $\begin{array}{l}\text { Income inequality (Gini } \\
\text { Coefficient) }\end{array}$ & 1.394 & 1.564 & 1.685 & 1.349 \\
\hline $\begin{array}{c}\text { Female head: } \% \text { of all } \\
\text { Families }\end{array}$ & 1.207 & 1.648 & 1.100 & 1.594 \\
\hline Black: \% of Population & 0.328 & 0.125 & 0.318 & 0.193 \\
\hline Hispanic: $\%$ of Population & 0.081 & 0.026 & 0.060 & 0.025 \\
\hline $\begin{array}{c}\text { Movers: } \% \text { of population } \\
\text { that moved in previous } 5 \\
\text { years }\end{array}$ & 1.539 & 1.671 & 1.598 & 1.948 \\
\hline $\begin{array}{c}\text { College: } \% \text { of population } \\
\text { age } 25+\text { with } 4 \text { years }\end{array}$ & -0.466 & -0.162 & -0.611 & -0.246 \\
\hline R-Squared & $80 \%$ & $51 \%$ & $76 \%$ & $62 \%$ \\
\hline
\end{tabular}

Bold font indicates significantly different from 0 at $\mathrm{p}<5 \%, 2$-tailed test. The sample for both 1990 and 2000 consists of the 200 largest counties by population in 1990 . 
Table 2

Criminal justice expenditures, 2003

\$billions

\begin{tabular}{|c|c|c|c|c|}
\hline & Total & Police & Judicial/legal & Corrections \\
\hline Local & 94 & 58 & 18 & 19 \\
\hline State & 66 & 11 & 16 & 39 \\
\hline Federal & 35 & 20 & 9 & 6 \\
\hline Total $^{\mathrm{a}}$ & 195 & 89 & 43 & 64 \\
\hline
\end{tabular}

Source: Bureau of Justice Statistics Sourcebook of Criminal Justice Statistics Online http://www.albany.edu/sourcebook/pdf/t122003.pdf

a. The total entries are computed by summing the column entries. Those sums disagree with the "total" statistics from the Sourcebook, which are: total, 185; police, 83; judicial/legal, 42; corrections, 61. 
Figure 1

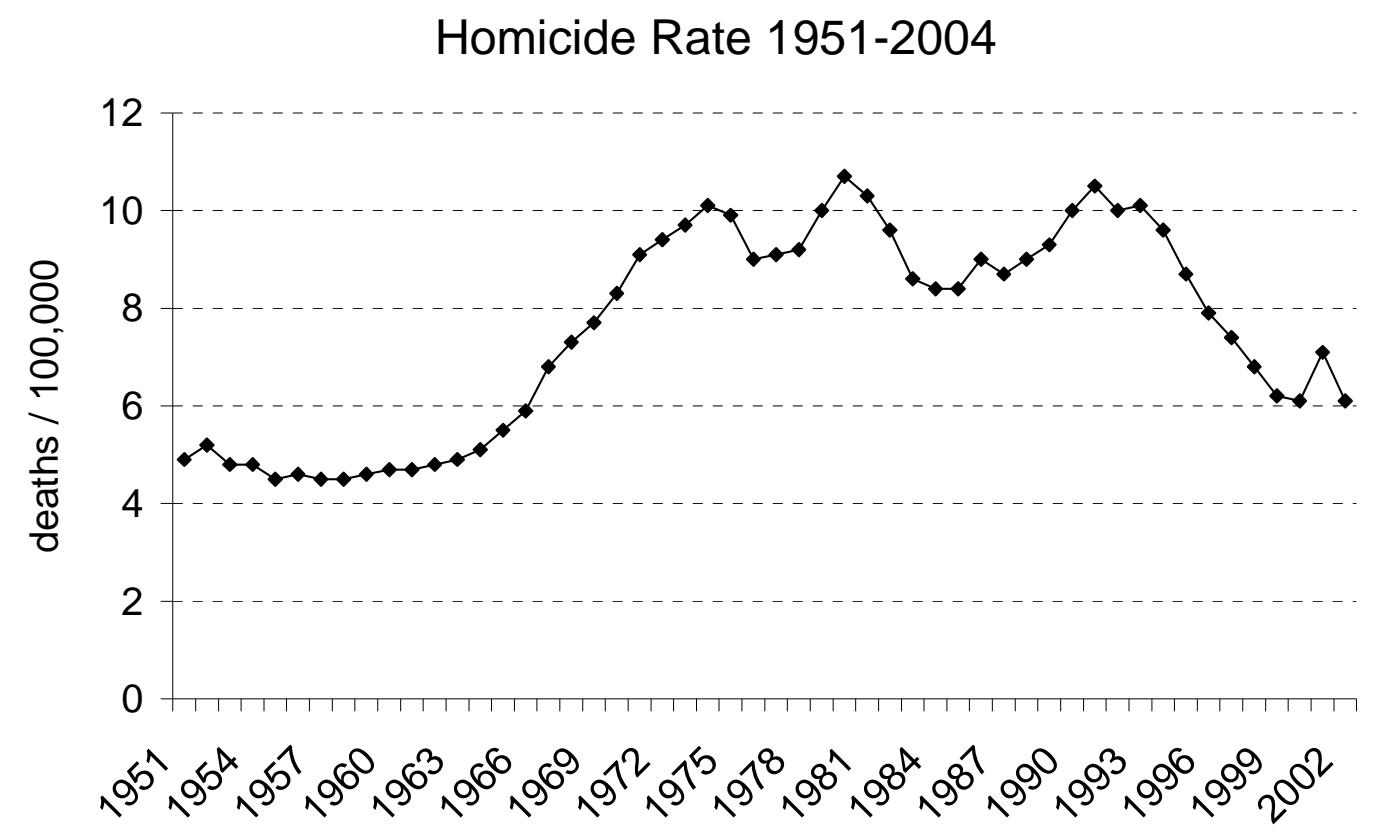

Source: National Center for Health Statistics

http://www.ojp.usdoj.gov/bjs/glance/tables/hmrttab.htm 
Figure 2

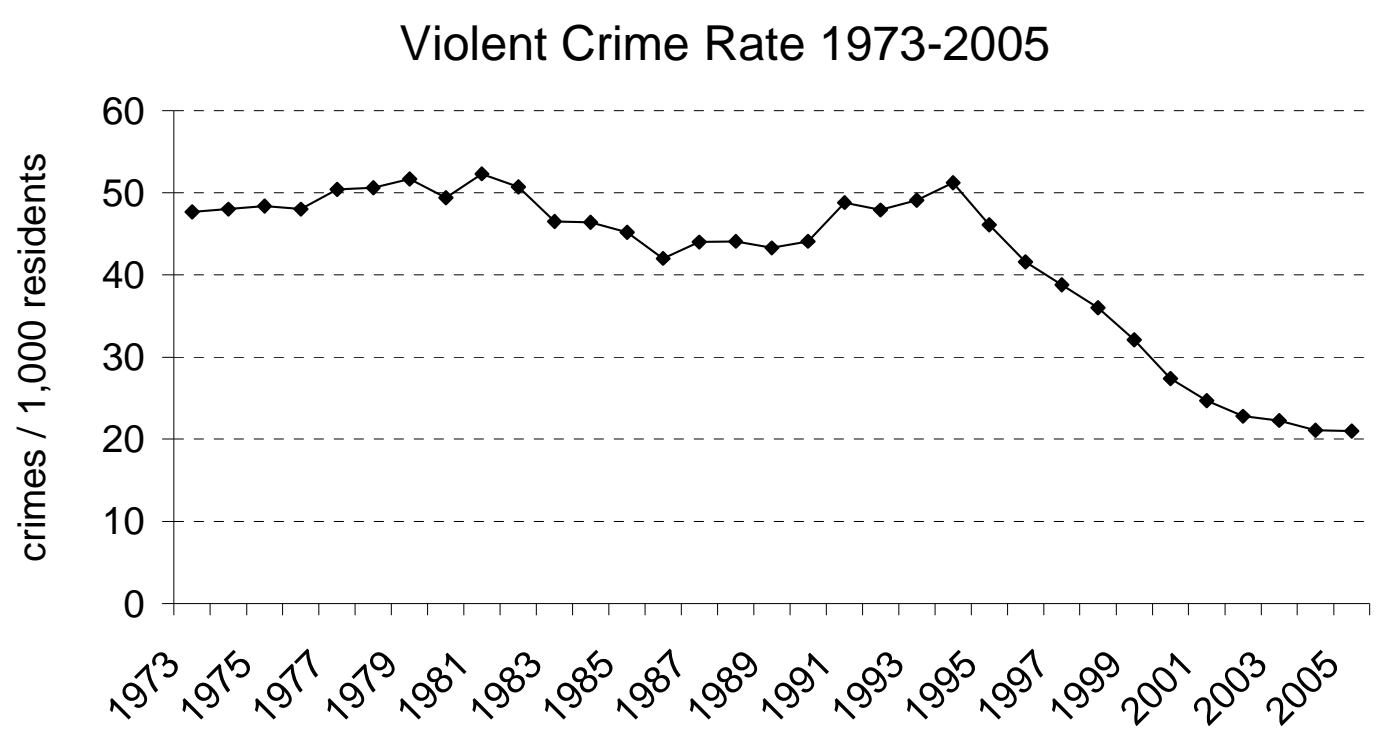

Note: Violent crimes included are rape, robbery, aggravated and simple assault, and homicide.

Source: National Crime Victimization Survey

http://www.ojp.usdoj.gov/bjs/glance/tables/viortrdtab.htm 
Figure 3

\section{Property Crime Rate 1973-2005}

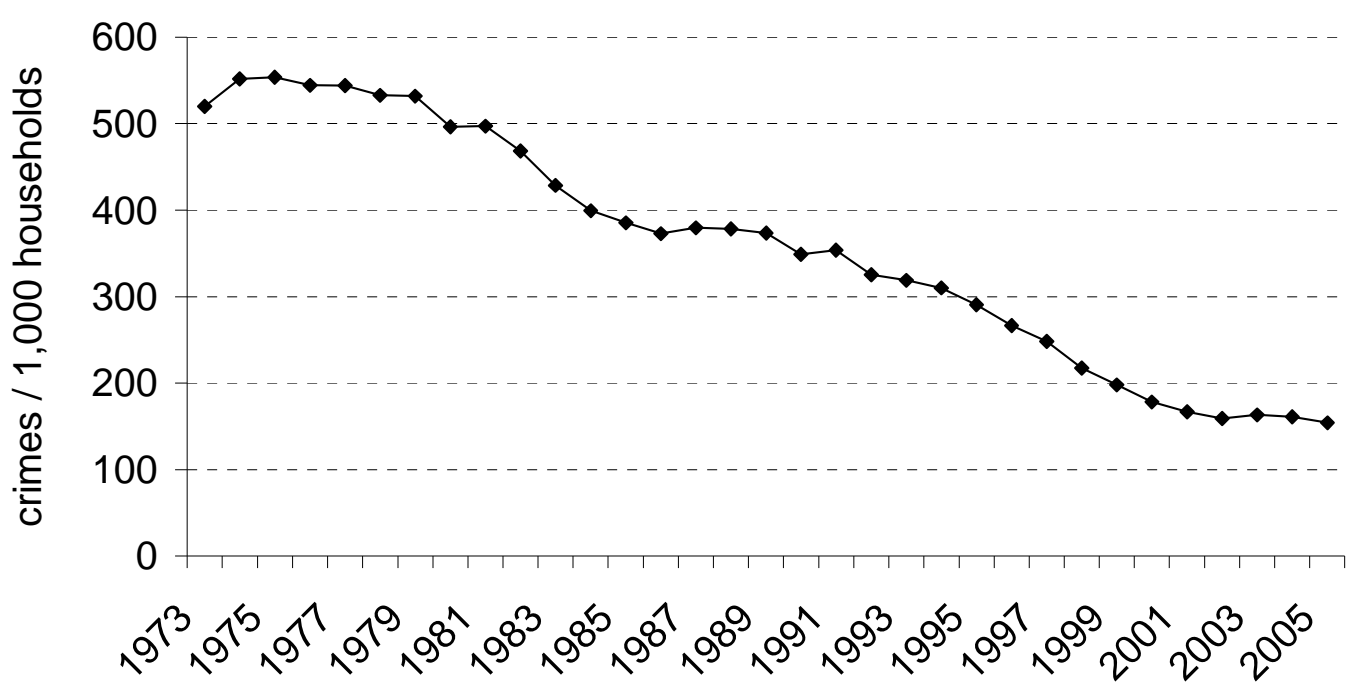

Note: Property crimes include burglary, theft, and motor vehicle theft. Source: National Crime Victimization Survey http://www.ojp.usdoj.gov/bjs/glance/tables/proptrdtab.htm 
Figure 4

\section{Direct Expenditure by Government Level}

(adjusted for inflation \& population growth)

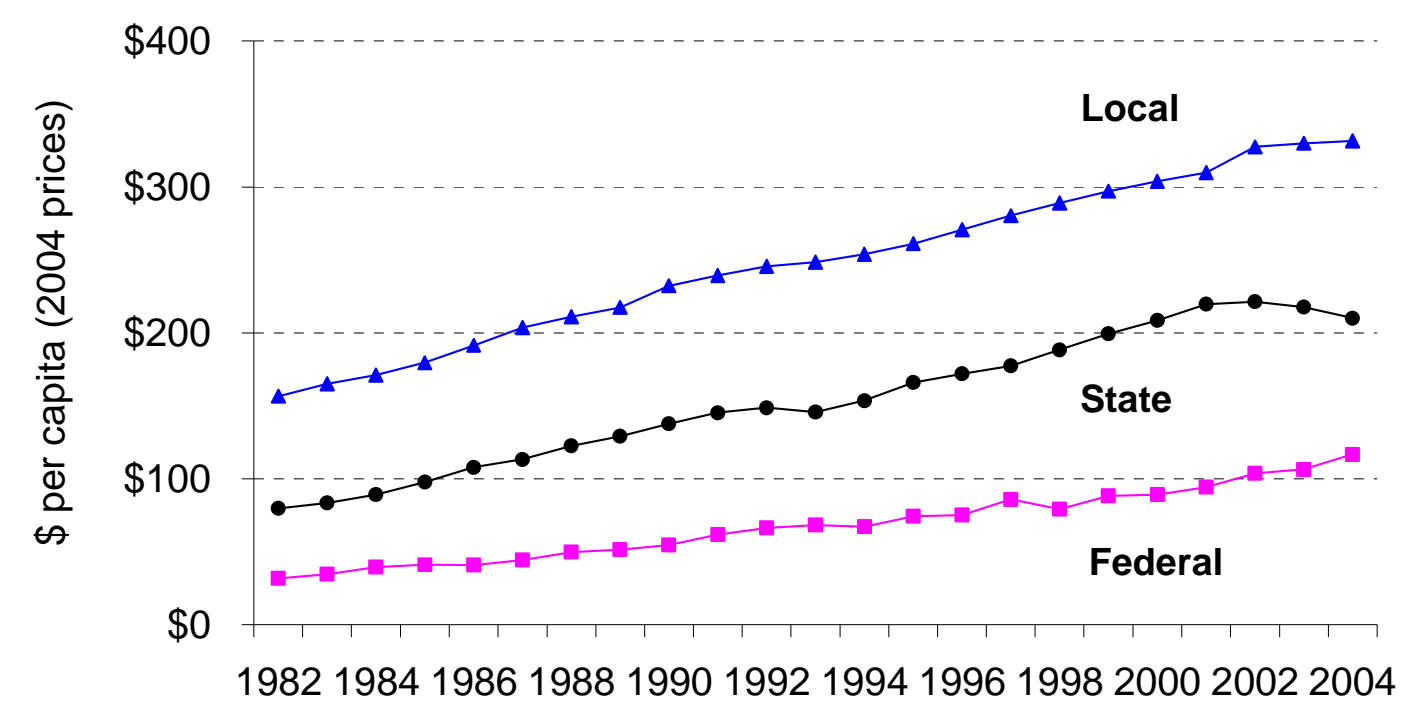

Source: Annual Government Finance Survey \& Annual Survey of Public Employment http://www.ojp.usdoj.gov/bjs/glance/tables/expgovtab.htm 
Figure 5

\section{Direct Expenditure by Criminal Justice Function (adjusted for inflation \& population growth)}

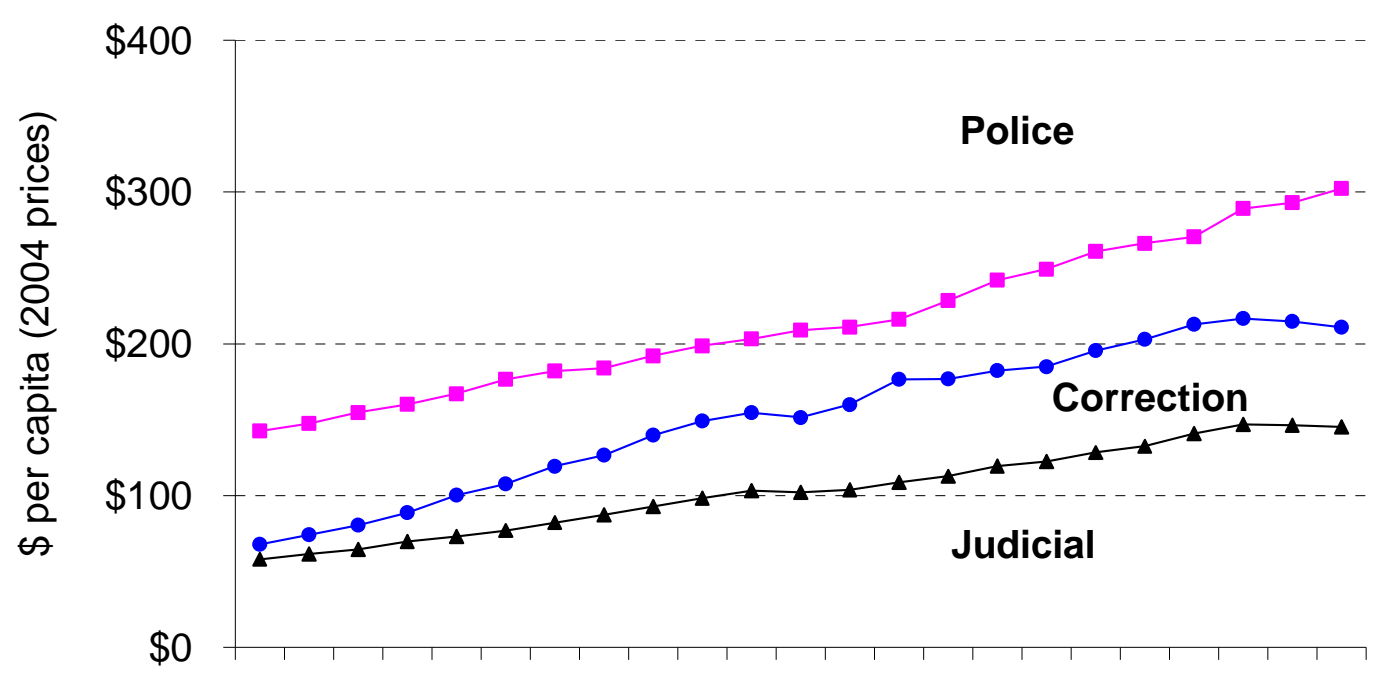

198219841986198819901992199419961998200020022004

Source: Annual Government Finance Survey \& Annual Survey of Public Employment http://www.ojp.usdoj.gov/bjs/glance/tables/exptyptab.htm 
End Notes

${ }^{1}$ Surprisingly the NCVS "uncovers" fewer of the most serious assaults than are known to the police. The NCVS estimate of the number of nonfatal gunshot wounds is low by a factor of 3, probably because so many of the victims are beyond the reach of the survey sampling frame - they are hospitalized or incarcerated or have no fixed address (Cook 1985).

${ }^{2}$ The FBI also manages the National Incident-Based Reporting System (NIBRS), in which police departments submit specified data items on each crime incident involving an Index crime. This program has low participation rate, and only covered about $16 \%$ of the U.S. population in 2003 (http://www.ojp.usdoj.gov/bjs/nibrsstatus.htm).

${ }^{3}$ It should be noted that the long-term trend in homicide rates is not an entirely reliable index of criminal behavior. Technological change in both medical treatment and in weaponry have changed the likelihood that a serious assault will result in the death of the victim. On the one hand, trauma care has improved a good deal, and the current homicide rate would be somewhat higher but for improved emergency medical response and lifesaving procedures for severely wounded victims. On the other hand, the firearms used by assailants have "improved," with increased power and rapidity of fire (Wintemute 2000).

${ }^{4}$ Glaeser, Sacerdote, and Scheinkman (1996) observe that "The high variance of crime rates across time and space is one of the oldest puzzles in the social sciences; this variance appears too high to be explained by changes in the exogenous costs and benefits of crime (507)." They analyze the effects of social interactions as a possible explanation 
for volatility, finding evidence that such interactions are particularly important for crimes of theft.

${ }^{5}$ For a systematic search for structural factors that influence state-level homicide rates, see Land, McCall and Cohen (1990).

${ }^{6}$ In particular, the following changes were made. First, his "\% nonwhite" was replaced with "\% black" and "\% Hispanic" for the sake of greater specificity. Second, his variable on police expenditures per capita was dropped, since it is plausibly the effect rather than the cause of crime. Third, also dropped was the "\% of population age 16-24"; he included it because that is the most crime-prone age group, but as it turns out its crosssection variation signals which counties have a relatively large population of college students - a group that is not particularly crime prone. He included the male unemployment rate, which did not perform well and was dropped in this specification. Finally, he reports the results of Poisson regression, while the results here are from ordinary least squares - a change that makes little difference in practice.

${ }^{7}$ While the unit of observation for these regressions is the county, the characteristics of the state in which the county is located may also be relevant. State governments provide a large share of the funding for the courts and criminal corrections, and differ with respect to criminal law and procedure as it affects robbery and criminal-homicide cases. States also differ with respect to the level of contribution to local finances and service provision. For these reasons I re-ran the regressions reported above controlling for the state in which the county is located. The results are very similar in all respects to those reported above. 
${ }^{8}$ Although robbery has long been the quintessential urban crime, in recent years robbery rates are about the same for mid-sized cities $(250,000-500,000)$ and larger cities. The same is true for homicide rates. For an analysis of why crime (used to) increase with the population, see Glaeser and Sacerdote (1999).

${ }^{9}$ The right interpretation of these results is also clouded by the aggregation problem. We are either observing the sum of individual propensities, or some characteristic that reflects interactions within the community. Robert Sampson, Stephen Raudenbush, and Fenton Earls offered the sociological view that the quality of interactions within the community, and particularly mutual trust, are important. They offer the term "collective efficacy" as a characteristic of communities that predicts the extent of informal social control that limits criminal activity (Sampson, Raudenbush \& Earls 1997; Harcourt \& Ludwig 2006).

${ }^{10}$ I ran regressions for changes in log crime rates, 1990-2000, as a function of changes in the independent variables, also in $\log$ form. I ran the same regressions for the period 1980-1990. None of the variables "perform" especially well. For robbery, 7 of the covariates have estimated coefficients that either switch signs across the two periods, or have "perverse" signs in both periods. "\% black" is significantly positive for the 1990s, but significantly negative for the $1980 \mathrm{~s}$. The $\mathrm{R}^{2}$ ranged from $0.4 \%$ to $7.0 \%$ for the four regressions.

${ }^{11}$ Doubling prison sentences will have an incapacitation effect that is less than double, since criminals tend to "age out" and desist from crime. Doubling prison sentences will have a muted deterrent effect because of the universal tendency to discount the future. 
The second five years of a ten-year sentence will tend to be heavily discounted relative to the first five years (Cook 1980).

${ }^{12}$ A National Research Council report concluded that there was adequate evidence to support a greater investment in cognitive-behavioral interventions with released prisoners; further, drug treatment coupled with frequent testing, and comprehensive multi-service employment and training programs, were deemed promising (National Research Council, 2008, p. 85).

${ }^{13}$ The receipts and employment for the private security industry are taken from the Economic Census for 2002, industry NAICS 5616 (excluding locksmiths). See http://www.census.gov/prod/ec02/ec0256i06.pdf for a complete report.

${ }^{14}$ Two other national surveys also provide estimates of the number of private security employees, the Current Population Survey and the US Census Bureau's County Business Patterns. Estimates for 2002 from the three sources are in rough agreement: 754 thousand (Economic Census), 724 thousand (Current Population Survey), and 715 thousand (County Business Patterns).

${ }^{15}$ In principle the increase in police presence could increase the number of arrests or reduce them, since additional police increase the probability of arrest per crime and reduce the number of crimes. The effect on the number of arrests (the product of probability per crime and number of crimes) will depend on the relative proportionate changes in these two variables. Possible relationships between crime, arrest, and policing are explored in Freeman, Grogger and Sonstelie (1996). 
${ }^{16}$ Further, there is a danger that affluent people will become less willing to support public policing if they are purchasing private protection (Bayley \& Shearing 2001: 30).

${ }^{17}$ The National Crime Victimization Survey for 2005 found that $40 \%$ of property crimes and $47 \%$ of violent crimes were reported to the police.

${ }^{18}$ It should be noted that self-protection activities can have negative externalities. Particularly problematic is the inclination to keep and carry firearms for self-protection purposes. Although the matter is hotly contested, the best evidence suggests that a high density of private gun ownership in a community increases both the homicide rate (Cook \& Ludwig 2006) and the burglary rate (Cook \& Ludwig 2003); the latter is probably due to the fact that firearms are easily fenced loot, so that communities with a high density of gun ownership are relatively lucrative to burglars. For a contrary view, see Philipson and Posner (1996).

${ }^{19}$ For example, Durham, North Carolina has organized the Community Response to Violent Acts for those crimes likely to engender retaliation. The Response consists of a door-to-door canvassing of the neighborhood where the crime occurred and the victim's residence by the Durham Police Department, partnering agencies and organizations, clergy, and concerned citizens. The canvass is designed primarily to develop investigative leads in the case by asking neighbors to come forward with information that may assist investigators in solving and prosecuting the case. 